\title{
Practical Guideline for the Restructuring of Enterprises Involving Consulting Services (on the Example of Ukrainian Industrial Enterprises) Anatoliy Kovalyov - Olha Vynokurova*
}

\begin{abstract}
:
The article examines the role of consulting services in the restructuring of enterprises. It describes how consulting firms help to increase the efficiency of enterprises and their value by providing information and recommendations. The work grounds the importance of the restructuring implementation adaptation for enterprises to external market conditions in order to increase their value and improve efficiency, competitiveness and market activity. The authors describe the stages of the restructuring and the participation of a consulting firm at each stage. The work shows the methodology of the restructuring with the involvement of consulting services. Our theoretical arguments are supported by case from the experience of the auditing company has conducted the restructuring in industrial enterprise. The example of implementation the restructuring of the organizational structure of the industrial holding in Ukraine through the services of an auditing company is given. This paper provides an effective way of the restructuring acceptable not only for industrial companies in Ukraine but also for enterprises that operate in a transitional economy.
\end{abstract}

Key words: Restructuring; Adaptation; Diagnostics of companies; Consulting services; the Company's value.

JEL classification: G34.

\section{Introduction}

Within market conditions, we may observe that even strong and developed companies often experience some difficulties which can be caused by both external and internal circumstances. In cases when the firm is not able to overcome arisen problems and difficulties on its own, the way out of the situation is to turn to professional consultants. However, companies resort to consulting services not only in case of problems happened but also when it becomes necessary to boost growth, optimize costs, adjust the management apparatus.

Anatoliy Kovalyov; Odessa National Economic University, Preobrazhenskaya Str. 8, 65082 Odessa, Ukraine, <kovalev@oneu.edu.ua>.

Olha Vynokurova; Odessa National Economic University, Preobrazhenskaya Str. 8, 65082 Odessa, Ukraine, <olga10888@mail.ru>. 
Kovalyov, A. - Vynokurova, O.: Practical Guideline for the Restructuring of Enterprises Involving Consulting Services (on the Example of Ukrainian Industrial Enterprises).

Therefore, enterprises have a constant need to make changes in their economic activities in order to ensure positive dynamics of key performance indicators. For this purpose, the most radical way is restructuring.

Restructuring allows enterprises to adapt to the constantly changing market conditions, to maintain their vitality, to increase their efficiency. Therefore, it is necessary to master innovative management methods, to change the organizational structure of management and production.

Restructuring is a labor-intensive process and it can not be carried out on its own, including conducting analytical work and developing a business plan, because often there is a lack of highly qualified specialists with certain skills. Therefore, owners of enterprises often resort to the services of consulting firms. Such firms accompany the restructuring process from the start to the finish. They take part in every stage of restructuring in order to minimize errors and achieve maximum results.

In recent years, the problem of the restructuring the enterprises is in the circle of view of the public administrations, business managers; it is also widely discussed in the scientific community. Problems of the enterprise's restructuring are reflected in the works of many contemporary foreign economists, among them are: M. Blaug (Blaug, M., 1992), E. H. Bowman \& H. Singh (Bowman, E. H. et al., 1999), K. Clark \& E. Ofek (Clark, K., and Ofek E., 1994), B. Gates (Gates, B., 1999), A. Kovalyov (Kovalyov, A, 2006), Patrick A. Gaughan (Gaughan, P. A., 2015), M. Porter (Porter, M. E., 1998), St. F. Reed (Reed, St. F., and Lajoux, A., 2007), Andrew J. Sherman (Sherman, A. J., and Hart, M. A., 2006), A. J. Strickland \& A. Thomson (Thompson, A. A., and Strickland, A. J., 1999), R. William (William, R., 2008) and others. However, scientists and practitioners do not have a unified approach to the mechanism of carrying the restructuring out at the enterprises by involve consulting services.

The purpose of the article is to substantiate the necessity of restructuring enterprises with the help of consulting services as a way to increase their efficiency, as well as to create and to increase the value of the enterprise by providing information and recommendations.

\section{Literature Review}

Executives restructure their enterprises to enhance productivity, to reduce costs and to increase shareholder wealth. Bowman (1999) investigated how restructuring affects the efficiency of activities and productivity of enterprises. But the influence of the restructuring on productivity has differed over time and also over countries. Our research focuses how restructuring impact on industrial 
enterprises which operate in the specific dynamic environment of Ukraine. I. Filatotchev (2003) describes the effects of the restructuring in transition economies. Authors focused on problems of governance in transition economies and showed benefits for companies after their restructuring. But the authors do not demonstrate how to achieve cost reduction in the restructuring and to achieve more effective results of this process.

We also support that the restructuring is an effective way to improve all performance indicators of the company. But this is a difficult process, which requires considerable expenses. Therefore it must be carried out by highly qualified and experienced specialists to achieve efficient results. Due to the lack of experienced staff in the enterprises, owners and managers often involve professional consultants for the restructuring. Usually, consultants are involved in the entire restructuring process. They start from defining the purpose of the restructuring, diagnostics the state of the company and end with the evaluation of the results and monitoring the state and conditions of activity.

The stage of diagnostics is most important in the process of restructuring. Because based on the results of diagnostics, consultants choose tools and methods for restructuring, types of restructuring, and develop a plan and a restructuring programme. In the scientific literature, there is a different classification of types and forms of restructuring. Bowman (1999) classified restructuring activities into three categories, portfolio restructuring, financial restructuring and organizational restructuring. However, the authors do not indicate in their study how to choose the type of the restructuring that must be carried out at a particular enterprise. In our article, we apply the method of identification of the forms of restructuring industrial companies in a transition economy depending on the phase of the enterprise's life cycle (Kovalyov, 2006).

The success of restructuring strategies depends on the value creation insights, which involve an understanding of consultants and company executives about how to improve the performance of the business. According to Campbell, Goold, and Alexander (1995) value creation insights are based on unique knowledge or experience of reasons why certain kinds of business have performance problems or fail to maximize their potential and ways in which managers can influence the business so as to raise performance.). Value creation insights are about major areas of improvement: raising performance, high improvement of the value of the business, return on sales and sales volume. Copeland, Koller, and Murrin (1990), Rappaport (1986) advocated for management based on value creation in a business.

Today, the Porter's Value Chain Model (1998) is widely used in practice of analysis and management of enterprises. Porter proved that the profitability of a 
Kovalyov, A. - Vynokurova, O.: Practical Guideline for the Restructuring of Enterprises Involving Consulting Services (on the Example of Ukrainian Industrial Enterprises).

firm is influenced by its industry structure and by the strategic choice it makes in positioning itself in the industry. In our study, we used the Porter's Value Chain (1985) in designing the model of the organizational framework of the industrial holding. Due to the evaluation of each link in the value chain, an effective restructuring model was developed. The implementation of this model allowed to achieve an increasing of the company's value and its competitiveness in the market.

Consulting firms adopt different approaches of value based financial management systems to address perceived problems of the existing financial management systems. Stern \& Stewart and Co. (Stern Stewart \& Co., 2000; Shil, 2009) introduced the EVA financial management system. EVA is defined as net operating profits after tax less a company's cost of capital (including the costs of both equity and debt) subject to a number of adjustments to data reported in financial statements. This indicator directs attention to the results created by managers and promotes that managers need to be rewarded for their achievement (Hailemariam, S., 2001). But this approach has its disadvantages. It takes a lot of time to assess EVA. But some studies advocate that the EVA is in pointing vital linkages between financial communication, financial structure, executive incentives and the design of management and financial accounting systems (Bromwich and Walker, 1998; O'Hanlon and Peasnell, 1998; Mouritsen, 1998). In our study, we give the case when advisers use EVA to evaluate the result of the restructuring.

\section{Motivation and Theoretical Background}

In industrialized countries with their market economy, advisory consulting services have long been an essential element of the infrastructure. In Ukraine, in the context of financial crisis, we can also observe the increase in demand for consulting services, consultations on financial security and enterprise development.

In modern conditions, organizations are constantly confronted with various difficulties in activities and with crisis situations. Management personnel often faces complex tasks while being inexperienced or lacking practice in the proposed activities. Thus the cooperation with consultants specializing in restructuring issues is required.

The essence of consulting lies in the provision of assistance to the client in order to increase the efficiency of activities and create value by providing information and recommendations. Consultants act as the catalyst of changes; they introduce new knowledge and experience of other organizations, which makes it possible to give recommendations to avoid difficulties and create an effective mechanism for 
financial control, preventing illegal or wrong actions on the part of enterprise management.

Consulting services in the sphere of strategic and anti-crisis management can be classified according to various criteria. Depending on the subject of consulting, the following services should be distinguished: analysis and diagnostics, development of programs for all procedures of strategic or anti-crisis management, property valuation, restructuring of enterprises and liabilities. Thus, one of the types of provided consulting services is the assistance and advice in the course of enterprise restructuring.

The restructuring is worldwide understood as the continuous process of improving the competitiveness of the enterprises by applying some complex measures to adapt business management system to market conditions that are constantly changing. In this interpretation, the concept of restructuring is marked by its main characteristics - adaptation.

The restructuring involves complex changes in areas of the enterprise's functioning: legal status, organizational structure, the structure of raised capital, the structure of the personnel, etc. The International Accounting Standard (IAS 37) defines the restructuring as a programme that is planned and controlled by managers and that substantially changes the scope of activity the enterprise or the way of these activities.

Analysing the world experience in the interpretation of the concept "restructuring of the company" and the practical results of its implementation, the authors are aware of the necessity for restructuring reforms as means of resolving the contradictions between the market needs and outdated approaches to enterprise management that will ensure the creation of the market-oriented enterprise.

To our mind, restructuring of the company is a complete transformation of its activities in accordance with the requirements of internal and external environment, and with the strategy of its development, which consists of changing the structure of production, assets, liabilities, and the system of management in order to improve production efficiency, the competitiveness of products in the markets, to raise market value growth (Kovalyov, A, 2006).

The expediency of implementing the restructuring of industrial enterprises in Ukraine can be justified by the trend of increasing the share of profitable enterprises in the real sector of the economy in the total amount for 2012-2016 by 16.8\% (State Statistical Service of Ukraine, 2012-2016) (Fig. 1). First of all, this positive dynamics is due to the fact that the methodology for restoring the solvency of enterprises and recognizing companies as bankrupt has been improved at the legislative level in Ukraine. Changes in the Ukrainian legislation on the 
Kovalyov, A. - Vynokurova, O.: Practical Guideline for the Restructuring of Enterprises Involving Consulting Services (on the Example of Ukrainian Industrial Enterprises).

recognition of enterprises as bankrupt have allowed to "clean" the real sector of economy from enterprises that do not actually operate and do not participate in the process of creating GDP, and sharply reduce the number of unprofitable companies. Also, enterprises that were experiencing signs of crisis (declining sales, business activity, and profitability) implemented strategic changes to overcome these crisis symptoms and improve their efficiency.

Fig. 1 Share of profit-making Ukrainian enterprises 2000-2016 (in \%)

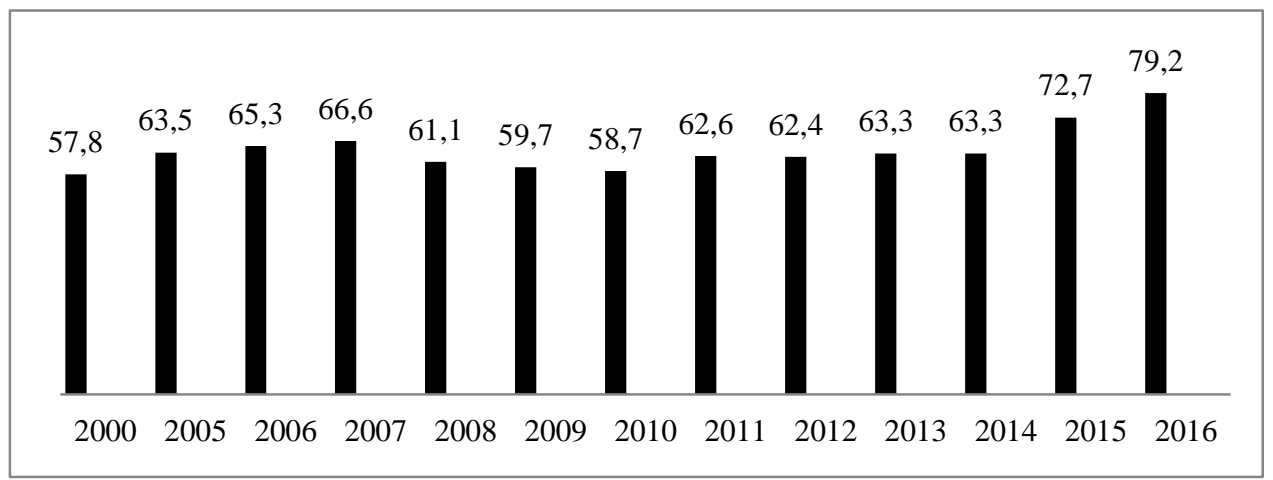

Source: Computation by data of State Statistical Service of Ukraine, 2012-2016.

As a rational argument for restructuring, the authors give an example of the practice of a large Ukrainian enterprise Odeskabel. It is the largest plant in Ukraine for the production of electrical products - cables. At this stage of its development, Odeskabel is permanently carrying out the preventive restructuring in order to maintain its leading positions in the domestic market and access to foreign markets. The plant is actively engaged in expanding the range of products, introducing innovations in production, improving manufacture, modernization and expansion of production, highly qualified personnel and organizations by the world standards (Information about the company Odeskabel). As a result of qualitative transformations, Odesskabel managed to achieve an increase in net asset value by $78.86 \%$ over the last 5 years (2012-2016) (Agency for the development of the infrastructure of the stock market of Ukraine, 2012-2016).

As a rule, the restructuring of the company is carried out under the following conditions. Firstly, when the company is in a deep crisis. The restructuring of enterprises implies overcoming the crisis and achieving normal sustainable financial and economic conditions. Secondly, the restructuring is necessary when the current situation of the company is satisfactory, but the forecasts for the nearest future indicate the specific problems and the threat of negative actions. Thirdly, the restructuring can be applied to the prosperous businesses that are growing rapidly. The aim of this restructuring is to increase separation from the 
competitors and to create a unique competitive advantage, ensuring a leadership position in the market. Thus, the restructuring is aimed at the development (Aistova, A, 2002). Thus, it can be stated that restructuring should be carried out permanently both in enterprises at the stage of crisis and recession and in successful enterprises at the stage of their development and peak.

Restructuring is a labour-intensive process that requires considerable costs from the enterprise. However, it is hardly possible to carry out restructuring on its own, including the diagnosis of the enterprise status, identifying problems, developing a business plan (restructuring programme), implementation of activities, analytical work, because businesses lack highly qualified professionals with the skills and experience of conducting reforms, who can carry out such events. Therefore typically, a strategically important economic and management decisions are taken with the assistance of consulting services of consulting firms. When it comes to the global or strategic restructuring, the participation of the subject in the process of restructuring is becoming an essential condition and guarantee of the effective results. Thus managers who have promptly resorted to the help of consultants experienced the benefits and effects of the development of the active marketing programmes, development of investment and financial policies, including the programme of financial rehabilitation and restructuring of enterprises.

\section{Methodology}

The practice of holding consultations on the restructuring of enterprises has developed the following range of activities in this sector: business process analysis and structuring of the company's business units; analysis of the financial condition of the company; analysis of the structure of the property complex; analysis of the company's position in the market and its prospects for change; Due diligence; development of the restructuring concept on the basis of variant calculations the efficiency of business organization; assessment of the business value; the formation of economic model of the company's functioning; development of a programme and a business plan of restructuring and organizational mechanism for its implementation; support of the restructuring programme implementation; assessment the results of the restructuring.

In view of the fact that the restructuring involves a profound recovery of industrial activity, the structure, and organization of the whole enterprise, requires considerable time and material costs of material and financial resources, the restructuring process should be carefully and deeply thought out. Making decisions of developing the restructuring programme and its practical implementation should be preceded by a comprehensive analysis of the initial state of production and marketing, economics and finance of enterprise. Based on this 
Kovalyov, A. - Vynokurova, O.: Practical Guideline for the Restructuring of Enterprises Involving Consulting Services (on the Example of Ukrainian Industrial Enterprises).

analysis the initial restructuring scheme is being formed, and later makes the grounds of the development the expanded restructuring programme.

In our opinion, the most effective type of such a comprehensive analysis is the consulting service "Due diligence". Due diligence is a term used for the performance of an investigation of a business, an investment, or a person with a certain standard of care (Flyvbjerg, B., 2013). The theory behind due diligence holds that performing this type of investigation contributes significantly to informed decision making by enhancing the amount and quality of information available to decision makers and by ensuring that this information is systematically used to deliberate in a reflexive manner on the decision at hand and all its costs, benefits, and risks (Bing, 2007; Chapman, 2006). Consulting firms usually provide this type of service before carrying out the restructuring itself. This allows evaluating all the risks while implementing investment projects and, based on the results obtained, make the right management decisions.

If you follow the basic principles of project management method, it is possible to distinguish several stages of the restructuring project.

The first stage is the definition of restructuring purposes. The owners and managers should determine what they are not satisfied with in the current activity of the company, and what they want to achieve as a result of structural changes. The further development of the company will depend on this step: how correctly they determine the objectives and scope of tasks.

The second stage is the company's diagnostics. It is carried out in order to identify the problems of the company, its strong and weak sides, to understand the prospects for the development and profitability of further investment in this business. The results obtained after diagnosing are an information basis for drawing up a project, program and business plan for restructuring. That is why this stage is extremely necessary and quite labour-consuming.

The diagnostic methodical toolkit is wide and varied. The practice of consulting firms shows that during the diagnostics specialists usually make legal and tax analysis of operational activity, evaluate market and investment allure of the company. Also, company's financial condition, strategy, and management operation activity are studied. In other words, a comprehensive analysis of the enterprise's activities is carried out.

Therefore, sometimes while restructuring, it is advisable to resort to such service of consulting firms known as "due diligence". Also at this stage, the consulting firm identifies the stage of the enterprise's life cycle, conducts a so-called Value Chain analysis. 
Value chain analysis occupies an important place in the process of diagnostics the enterprises. Understanding how your company creates value and looking for ways to add more value, are critical elements in developing a competitive strategy.

We believe, that Michael Porter's Value Chain concept (Porter, M., 2006) is the most suitable for analysing the value creation chain. This concept serves as a tool for analysing the formation of value and developing recommendations to increase it and improve the competitiveness of the enterprise. Within the framework of the concept, the competitiveness of an enterprise is viewed in two ways: from the point of view of value formation and from the point of view of its redistribution between the participants who create the final product. In our opinion, the value chain is suitable for composing business models of enterprises that are subject to restructuring. While developing a business model, the consulting firm evaluates each link in the value creation chain, establishes the proportions of cost distribution among the participants in the chain, determines the main link, and works out recommendations for increasing the value. So, it provides an analysis of business processes and creates the structure of all business units of the company. In its turn, it allows achieving growth in value.

Thus, a complete and thorough diagnosis is a necessary condition for successful transformations. Without a precise knowledge of the situation, it is impossible to formulate correctly the goals of restructuring, to create a business model, to choose the form and ways of restructuring, taking into account the specifics of the activities and development of an exact company, to determine the composition and sequence of actions for carrying out the reforms. Diagnostics greatly reduces the number of errors in the selection and implementation of transformations and therefore allows you to achieve maximum results.

The third stage of restructuring is the development of strategy and restructuring program. At this stage, according to the results of the diagnosis, several alternatives of the company's development are prepared. For each option the methods of restructuring are defined, forecast figures are calculated, risks and volume of resources involved are estimated. On the basis of various criteria, the company owners and managers are assessing the effectiveness of alternatives and making the choice, in accordance with which the restructuring programme is developed. This formalizes and clarifies the strategic objectives of the company, details qualitative and quantitative target parameters, which the system is going to reach, taking into account resource restrictions.

It should be noted that the impact of restructuring on the efficiency of the enterprise as a whole, its business processes and business units will vary depending on the main forms and methods of restructuring that the consulting firm determines, taking into account the results obtained at the stage of diagnosis. 
Kovalyov, A. - Vynokurova, O.: Practical Guideline for the Restructuring of Enterprises Involving Consulting Services (on the Example of Ukrainian Industrial Enterprises).

Professor A.I. Kovalyov in his research of the management of enterprise restructuring (Kovalyov, A, 2006) identifies the forms of restructuring depending on the phase of the enterprise's life cycle. According to this criterion, the author distinguishes the following forms of restructuring.

At the stage of ascent, adaptive restructuring should be used, which includes a number of "soft", "sparing" adjustments to the current activities of the company in accordance with changing market requirements.

At the stage of maturity, organizational and managerial restructuring is appropriate. It will provide the restructuring of the management system for business orientated structural divisions of the enterprise.

Organizational restructuring is a significant change in the organizational structure of the firm, including divisional redesign and employment downsizing (Bowman, E. H. et al., 1999).

At the stage of stagnation, financial restructuring is being undertaken.

Financial restructuring represents significant changes in the capital structure of a firm, including leveraged buyouts, leveraged recapitalizations, and debt for equity swaps (Bowman, E. H. et al., 1999).

At the stage of the crisis, it is necessary to conduct a set of measures provided by the procedure for conducting a bankruptcy case, which is aimed at restoring the paying capacity of a debtor enterprise.

In the authors' opinion, this approach allows, in accordance with the specifics and stage of development of a particular enterprise, to choose the most appropriate type of restructuring, to determine the methods of its implementation and to develop a restructuring program. In accordance with this approach, consulting firms, while participation in the restructuring process of enterprise, initially determine the life cycle stage, make the comprehensive analysis of company position and its correspondence to the life cycle stage, and then recommend a specific type of restructuring that meets the specifics of the enterprise and its functioning characteristics on the revealed stage of development.

The fourth stage is the implementation of the restructuring in accordance with the developed programme. A team of experts involved in the work is formed. The team should carefully study all stages of the programme. And then each stage is consistently implemented. During the fourth stage of the restructuring, the targets are specified and, if there is some deviation from the planned values, the company carries out the adjustment programme.

The fifth stage is the evaluation of restructuring results. At the last stage the team responsible for the implementation of the programme will oversee the 
implementation of targets, analyse the results and prepare a final report on the work done.

The consequences of restructuring can be conceptualized in terms of a sequence of intermediate effects, which may have positive or negative outcomes. In the case of portfolio restructuring, these intermediate effects could lie in the increased strategic focus, greater economies of scope, more cogent control of multiple business units. In the case of financial restructuring, these intermediate effects could be expressed as an emphasis on cash flows and changes in managerial incentives. In the case of organizational restructuring, these effects could be represented in greater employee satisfaction, reduced turnover, increased efficiencies and better communication. Ultimately, these intermediate effects may have some impact on the financial performance or economic wealth of the corporation. This ultimate effect may be perceptible in a few years or over a longer time period (Bowman, E. H. et al., 1999).

Bowman E. H. and Singh H. distinguish between two measures of company performance in the wake of a restructuring (Bowman, E. H. et al., 1999):

- market performance as abnormal movements in the firm's stock price

in the days after a restructuring announcement; abnormal returns reflex changes in a company's share price, adjusted for market trends, that can be attributed to the restructuring event; and

- accounting performance as changes in financial measures of the

company's performance, including return on equity and return on investment; these changes are typically calculated over a several-year window surrounding the restructuring event, allowing comparison of post-restructuring accounting performance with the pre-restructuring record.

Some studies, such as that of Clark and Ofek (Clark, K., and Ofek E.,1994), examine both accounting and market-based performance measures. However, most opt for one approach or the other.

In our opinion, the most informative indicators for assessing the results of restructuring made by consulting firms, are certainly the accounting figures for Ukrainian enterprises. For example, net profit, return on assets, return on equity and return on investment, EVA indicator can be named. In this article, we give an example when EVA indicator was used as an assessment indicator of the results of restructuring made by the audit company. This indicator allows assessing the efficiency of restructuring from the position of owners. It also allows to determine the market value of the enterprise, as well as to evaluate the efficiency of business units or individual property complexes. 
Kovalyov, A. - Vynokurova, O.: Practical Guideline for the Restructuring of Enterprises Involving Consulting Services (on the Example of Ukrainian Industrial Enterprises).

Consulting company participates in all stages of enterprise restructuring, beginning with an analysis (diagnosis) of the external and internal environment of the enterprise, including the development of the strategic development plan of the company, development of a business plan of enterprise growth, implementation the activities themselves and organizational restructuring procedures, and ending with the return to regular management, control over the indicators.

The article below shows how it is done in practice. As an example, we give the case in the practice of audit company Ernst \& Young Global Limited, which participated in the development and implementation of the restructuring project of large agro-holding in Ukraine.

\section{Results and Discussion}

For a better understanding of the procedure and method of restructuring involving consulting services, the authors have studied the practices of the organizational restructuring on the example of Ukrainian agro-holding Risoil S.A., engaged in the production and marketing of agricultural products (www.risoil.com/about/). The main task of the holding company is the concentration of production and financial capacity to centralize the production, marketing, and supply activities as well as management of product assortment and finance. The shareholders detected the failure in execution of the main tasks of strategic development, and consequently, it was decided to restructure the company's organizational structure, which would further allow the control system not to lose flexibility, efficiency and to avoid reducing the efficiency of the entire operation.

The shareholders of the investigated companies came to the decision to conduct the restructuring with the help of consulting services of auditing company Ernst \& Young Global Limited.

The process of the restructuring was fully accompanied by the auditing firm. The initial step included diagnostics of the internal and external environment of the holding operation, analysis of financial and economic conditions, determining the phase of the holding's life cycle, operational analysis of holding participants, as well as the analysis of structural relationships between entities within the holding.

The consultants determined that holding is at its maturity stage. Therefore, taking into account the results of diagnostics, as well as the identified stage of life cycle, it was recommended to use organizational and management restructuring.

Also, Ernst \& Young consultants analysed the value chain creation in the holding company, identified the main links of the chain and their components (companies participating in business processes) (Fig. 2). The results obtained by value chain analysis allowed to develop a model of the organizational structure according to a 
criterion of optimizing participation of holding companies in each link of the chain.

Fig. 2 The existing model of the organizational structure of Risoil S. A.

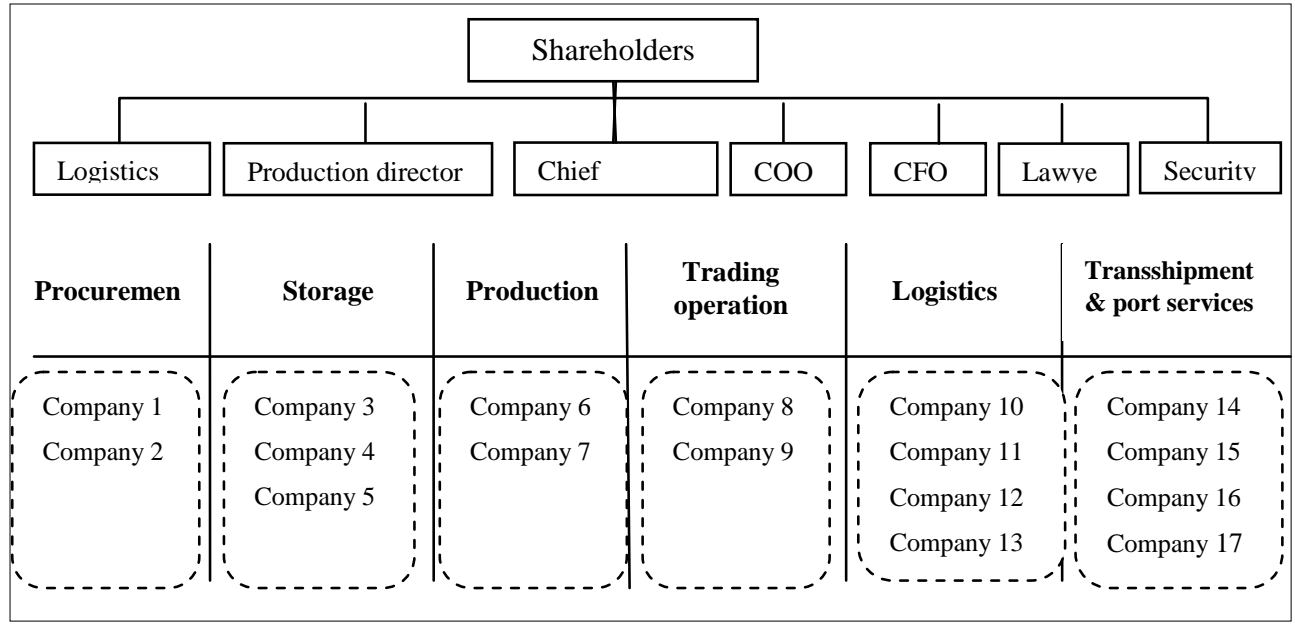

Source: Research results.

The advisers evaluated the distribution of functions between companies and carried out analysis of management decisions being taken in the group of holding companies-participants.

In the process of restructuring, it was planned to make the separation of powers in the system of "holding companies" as well as within companies themselves. Experience shows that the value of shares after a restructuring of holdings is usually increased by boosting the profitability of shareholders in both the holding company and its subsidiaries.

Thus, the aim of restructuring in the agricultural holding under study is the transformation of the organizational structure of the company to optimize the production, sales, supply, and management. Implementation of the developed organizational restructuring programme is aimed at achieving long-term goals. As a result of this success, it is predicted increasing flow of net present value of future revenues, boost in investment attractiveness and competitiveness, expansion of markets and the growth of the market value of its equity.

As a result of diagnostics, the consultants identified strong and weak sides of holding, its problems, threats and potential opportunities. Figure 1 presents the results of diagnostics in the form of the SWOT-analysis (Tab. 1). 
Kovalyov, A. - Vynokurova, O.: Practical Guideline for the Restructuring of Enterprises Involving Consulting Services (on the Example of Ukrainian Industrial Enterprises).

Tab. 1 SWOT-analysis of Risoil S. A.

\begin{tabular}{|c|c|}
\hline $\begin{array}{l}\text { Strong sides } \\
\text {-Personal relationship of trust with } \\
\text { shareholders directors } \\
\text { - Highly qualified specialists } \\
\text { - Diversification of products / services } \\
\text { and product groups (cargo), with a focus } \\
\text { on the agricultural sector } \\
\text { - Extensive experience in logistics and } \\
\text { port handling } \\
\text { - The largest trans-shipment terminal }\end{array}$ & $\begin{array}{l}\text { Weak sides } \\
\text { - Poor cooperation between companies } \\
\text { of the group } \\
\text { - The lack of quality information for } \\
\text { management decisions } \\
\text { - Lack of a balanced scorecard for the } \\
\text { planning and control of the company } \\
\text { - Weak delegation of authority at all } \\
\text { levels } \\
\text { - Low standardization of processes }\end{array}$ \\
\hline $\begin{array}{l}\text { Opportunities } \\
\text {-Increase the manageability of group, } \\
\text { coordination and standardization of the } \\
\text { companies' activities } \\
\text { - Expanding the scope of activities with } \\
\text { new services to existing and new } \\
\text { customers } \\
\text { - Redesigning of complexes and } \\
\text { development of new business trends } \\
\text { - Reducing costs by standardizing } \\
\text { processes } \\
\text { - Improving the efficiency of staff }\end{array}$ & $\begin{array}{l}\text { Threats } \\
\text { - Increasing competition and loss of } \\
\text { market share } \\
\text { - The risk of outflow the professional } \\
\text { staff } \\
\text { - The threat of default due to the } \\
\text { problems of unclear power division } \\
\text { - Rejection of changes by the staff } \\
\text { - Actions of state controlling bodies }\end{array}$ \\
\hline
\end{tabular}

Source: Research results.

Advisors developed recommendations for the restructuring of the agricultural holding based on the results of diagnosis the current state of holding and its constituent units. It was suggested that the companies of Risoil S. A. should be combined into divisions in order to improve customer service, business process standardization and the quality of planning and control. It was also proposed to create a corporate centre in the corporate governance structure and to distinguish there the service operating support functions for standardization and centralization of holding management. The consultants recommended forming the Board of Directors out of shareholders, division leaders and the head of Corporate Centre, which will make decisions on strategic management.

Consultants have developed several options for holding corporate management organizational structure and selected the most suitable option, which allows taking into account the specifics of holding relations. There were developed three forms of organizational and job integration in the holding: elementary, minimally required and most appropriate. The most expedient (recommended) model of organizational and job integration of the holding is shown in Fig. 3. 
Management decisions that are taken in Risoil S. A. company may be divided into four groups, which are later possible to draw to a certain level of corporate management structure. Shareholders make following decisions: the development of new businesses; attracting customers; liquidity and money management; M\&A strategy/asset sale; relations with regulators. Board of Directors: development of new products/services; procurement strategy; outsourcing operations/functions; the appointment/dismissal of top managers; corporate strategy and business unit strategy; activity indicators and budgets. Heads of Divisions: making the decision about work with clients; pricing of products; services, terms, conditions of contract; accounting the costs; selection of suppliers; relations with agents/brokers; reconciling the payments; project management; purchase/sale of equipment. Corporate Centre: evaluation of the effective use of equipment; promotion and advertising expenses; financial reports and accounting policies; selection of suppliers of its systems; a legal regulation; financial control; economic security; HR management policy.

Fig 3 The version of the recommended model of the corporate management structure Risoil S. A. (strategy is formed at divisional level)

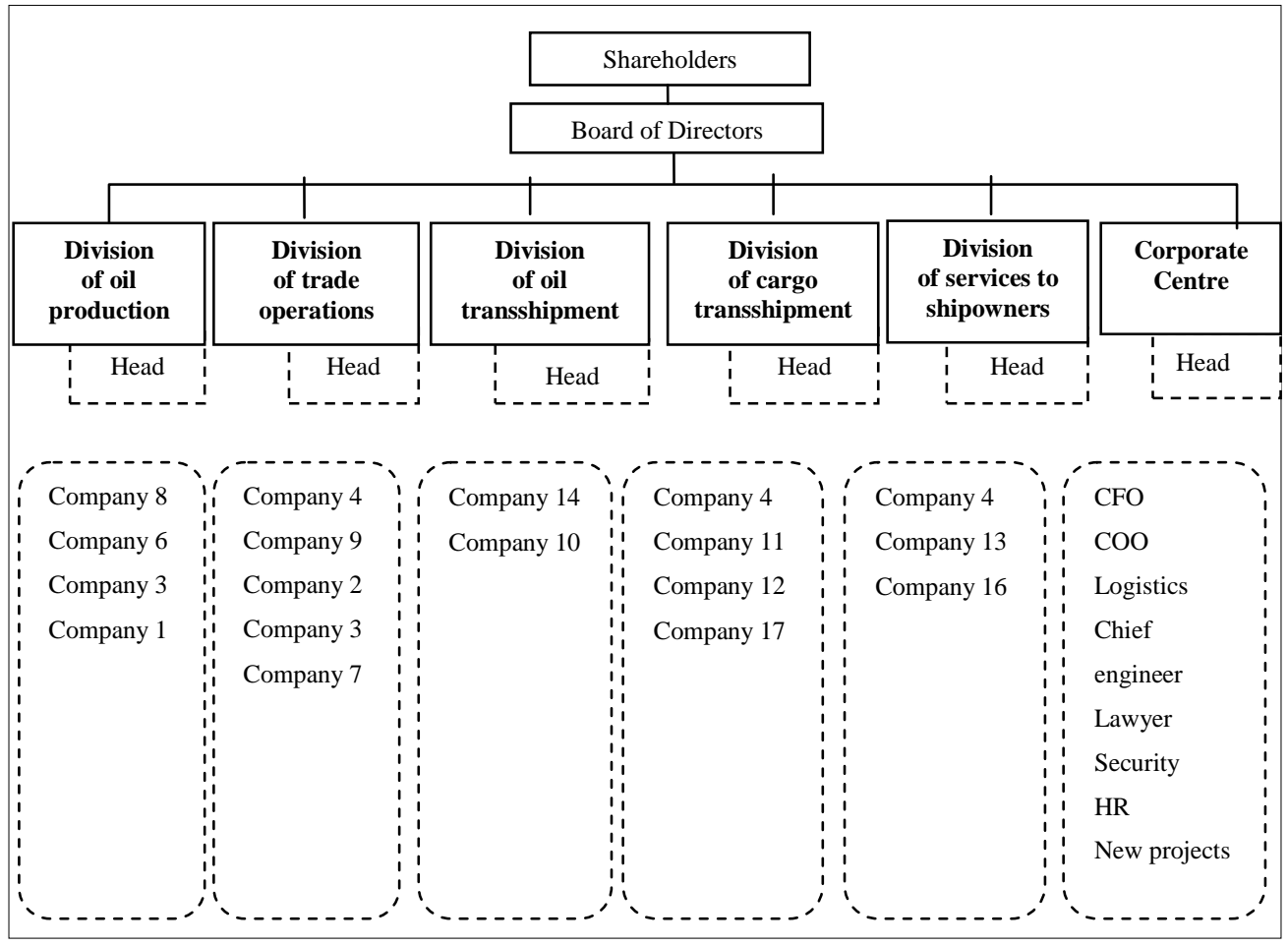

Source: Research results. 
Kovalyov, A. - Vynokurova, O.: Practical Guideline for the Restructuring of Enterprises Involving

Consulting Services (on the Example of Ukrainian Industrial Enterprises).

Advisors used EVA indicator as an indicator of the estimated results of the restructuring. According to confidential data of the consultants the company's market value of Risoil S. A. in the case of effective restructuring and implementation of all recommendations will increase by $18 \%$ during the first three years. In further research, we will conduct an empirical study of the impact of quantitative and qualitative factors on the EVA indicator in the process of restructuring.

\section{Conclusion}

The conducted study allows us to conclude that the restructuring is one of the most effective ways to increase the capitalization of business, its competitiveness, financial stability and business activity. According to the authors, consulting services used in the restructuring process, will increase the economic efficiency of restructuring programmes by well-grounded choice of complex measures of legal, organizational and administrative, financial and technological nature to bring the company out of the crisis, raising its competitiveness and quality in study of project solutions in the field of strategic and operational management of the company.

The literature review reveals that the restructuring is equally used both in developed countries and in transition economies. The restructuring experience of the developed economies shows that the restructuring creates value and it does not bring change in management of the company. The restructuring experience of transition economies showed that there is even a greater need for the restructuring of enterprises than in those enterprises in the developed economies.

A feature of the restructuring of enterprises in a transitional economy is that the state sometimes participates in this process. But basically, the state supports a large business that is more conducive to macroeconomic development than the medium and small business. Therefore, it can be argued that the state's participation is insignificant in the process of restructuring companies in the transition economy. The state allocates funds for the implementation of programs of individual large industrial enterprises. Due to the lack of state support, small and medium-sized enterprises in Ukraine are unable to carry out large-scale restructuring. Usually, they carry out current changes in the activity on their own. They carry out the transformations based on the experience, knowledge, and intuition of managers because consulting service in Ukraine is expensive. The large industrial enterprises often use services of consultants in the restructuring process because they have more financial opportunities than small and mediumsized enterprises. Despite the fact that consultants are fully involved in the restructuring process, company executives also participate in it. Since the 
managers know more about the company than advisors they can introduce changes in operations and investments once they get access to finance (Bowman, 1999).

Ultimately, further study should explore links between restructuring efforts and post-restructuring firm performance. We should also research features of value creation in the restructuring process. The scope of this article presents the concept of restructuring with the involving consulting services in the transition economy. This study is the conceptual framework for future research that may help to translate our common propositions into more specific hypotheses that may be subject to empirical tests.

\section{References}

Agency for the development of the infrastructure of the stock market of Ukraine, 2016. Kyiv, Ukrain. Available from: <http://smida.gov.ua/>. [1 January 2017].

Aistova, A., 2002. Restructuring enterprises: management issues. Alpina Publisher, Moscow.

Bing, G., 2007. Due Diligence: Planning, Questions, Issues. Praeger Publishers, Santa Barbara.

Blaug, M., 1992. Methodology of Economics. Cambridge Univ. Press, Cambridge. Bowman, E. H., Singh, H., Useem, M., Bhadury, R., 1999. When does restructuring improve economic performance? California Management Review 2, 33-54. DOI: $10.2307 / 41165985$.

Bromwich, M., Walker, M., 1998. Residual income past and future. Management Accounting Research 4, 391-419. DOI: 10.1006/mare.1998.0091.

Campbell, A., Goold, M., Alexander, M., 1995. Corporate Strategy: The Quest for Parenting Advantage. The Magazine Harvard Business Review. The march-april ISSUE. Available from: <https://hbr.org/1995/03/corporate-strategy-the-quest-forparenting-advantage>. [7 May 2003]. DOI: 10.1016/s0024-6301(98)00017-X.

Chapman, C. E., 2006. Conducting Due Diligence. New York, NY: Practicing Law Institute.

Copeland, T. E., Koller, T., Murrin, J., 1990. Valuation: Measuring and managing the value of companies. New York: Wiley. DOI: 10.2307/2328707.

Clark, K., Ofek, E., 1994. Mergers as a Means of Restructuring Distressed Firms: An Empirical Investigation. Journal of Financial and Quantitative Analysis 4, 541565. DOI: $10.2307 / 2331109$.

Filatotchev, I., Wright, M., 2003. Governance, organizational capabilities, and restructuring in transition economies. Journal of World Business 4, 331-347. DOI: 10.1016/j.jwb.2003.08.019. 
Kovalyov, A. - Vynokurova, O.: Practical Guideline for the Restructuring of Enterprises Involving Consulting Services (on the Example of Ukrainian Industrial Enterprises).

Flyvbjerg, B., 2013. Quality control and due diligence in project management: Getting decisions right by taking the outside view. International Journal of Project Management 5, 760-774. DOI: 10.1016/j.ijproman.2012.10.007.

Gates, B., 1999. Business at the Speed of Thought: Succeeding in the Digital. Economy Grand Central Publishing, New York. DOI: 10.1111/1467-8616.00097.

Gaughan, P. A., 2015. Mergers, Acquisitions, and Corporate Restructurings. John Wiley \& Sons, Inc., Hoboken, New Jersey. DOI: 10.1002/9781118269077.

Hailemariam, S., 2001. Corporate value creation, governance and privatisation: restructuring and managing enterprises in transition Groningen: s.n. Research of University of Groningen.

IAS 37 - Provisions, contingent liabilities and contingent assets. Available from: <https://finotchet.ru/articles/154/>. [17 December 2014].

Information about the company Odeskabel. Official site. Available from: <http://odeskabel.com/main-rus/about-company.html>.

Information about Risoil S. A. Available from: <http://www.risoil.com/about/>.

Kovalyov, A., 2006. Management of enterprises restructuring. AVRIO, Kyiv.

Mouritsen, J.,1998. Driving growth: Economic Value Added versus Intellectual Capital. Management Accounting Research 4, 461-482. DOI: 10.1006/mare.1998.0090.

O'Hanlon, J., Peasnell, K., 1998. Wall Street's contribution to management accounting: the Stern Stewart EVA ${ }^{\circledR}$ financial management system. Management Accounting Research 4, 421-444. DOI: 10.1006/mare.1998.0089.

Porter, M. E., 1998. Competitive Strategy: Techniques for Analyzing Industries and Competitors. Free Press, New York.

Porter, M., 2006. Competitive advantage: How to achieve good result and provide its stability. Alpina Business Books, Moscow.

Publication of documents of the State Statistical Service of Ukraine. Available from: <http://Ukrstat.org>. [1 January 2017].

Rappaport, A.,1986. Creating shareholder value: The new standard for business performance. New York. The Free Press, A Divisio of Macmillan Publishers.

Reed, St. F., Lajoux, A., 2007. The Art of M\&A: A Merger Acquisition Buyout Guide. McGraw-Hill Education, New York.

Sherman, A. J., Hart, M. A., 2006. Mergers \& acquisitions from A to Z. AMACOM Div American Mgmt Assn, New York.

Shil, N. C., 2009. Performance Measures: An Application of Economic Value Added. International Journal of Business and Management 3. 169-177. DOI: 10.5539/ijbm.v4n3p169. 
European Financial and Accounting Journal, 2017, vol.12, no. 3, pp. 171-190.

Stern Stewart \& Co., 2000. Available from: <http://www.sternstewart.com/ index2.shtml>. [20 January 2000].

Thompson, A. A., Strickland, A. J., 1999. Strategic Management:Concepts and Cases McGraw-Hill Companies. DOI: 10.1017/s1833367200006465.

William, R., 2008. Marketing. McGraw-Hill/Irwin. 
